\title{
German Cinematic Expressionism in Light of Jungian and Post-Jungian Approaches
}

\author{
Christina Stojanova \\ University of Regina (Canada) \\ E-mail: Christina.Stojanova@uregina.ca
}

"True symbolism occurs where the particular represents the more general [...] as living, momentary revelation of the unfathomable." Johann Wolfgang von Goethe, 1949, no. 314.

\begin{abstract}
Prerogative of what Jung calls visionary art, the aesthetics of German Expressionist cinema is "primarily expressive of the collective unconscious," and - unlike the psychological art, whose goal is "to express the collective consciousness of a society" - they have succeeded not only to "compensate their culture for its biases" by bringing "to the consciousness what is ignored or repressed," but also to "predict something of the future direction of a culture" (Rowland 2008, italics in the original, 189-90). After a theoretical introduction, the article develops this idea through the example of three visionary works: Arthur Robison's Warning Shadows (Schatten, 1923), Fritz Lang's The Weary Death aka Destiny (Der müde Tod, 1921), and Paul Leni's Waxworks (Wachsfigurenkabinett, 1924).
\end{abstract}

Keywords: Symbolism, Expressionism, semiotic vs. symbolic approach, psychological vs. visionary art, shadow, animus/anima, FaustMephistopheles dyad.

This essay argues that the longevity of German Expressionist cinema as a unique expression of the complex historical, cultural, and psychological environment of the Weimar republic (1918-1933), is above all predicated on its sophisticated cinematic language, defined as "symbolic expression" of "illogical and irrational factors, transcending our omprehension," which "cannot be dealt with rationally" (Jung qtd. in Smythe 2012, 151). Indeed, as has been noted (Guffey 2016), the most popular medium of the day invariably displays affinity to irrational and often times tabooed factors, related to sex and madness, but above all - to death and the occult. German filmmakers were among the firsts to see "the possibilities of film [...] as a method of transmitting" spiritual knowledge, marginalized by 
modernity, and simply moved in to occupy the niche (Guffey 2016, 171). And while The Student of Prague (Der Student von Prag, Paul Wegener and Stellan Rye, 1913) and The Golem (Der Golem, Henrik Galeen and Paul Wegener, 1915) appeared well before the officially endorsed beginnings of German cinematic Expressionism, their remakes - by the same crew and under the same titles went to become staples of its canon.

According to Siegfried Kracauer's book From Caligari To Hitler: A Psychological History of the German Film, published in 1947, these early works "introduced to the screen the theme that was to become an obsession of the German Cinema: a deep and fearful concern with the foundations of the self," and the place of that self within the increasingly destabilized world of Wilhelmine Germany (1974, 30). Lotte Eisner, in her 1952 book, The Haunted Screen: Expressionism in the German Cinema and the Influence of Max Reinhardt, alludes also strongly to the metaphysical tendencies of what came to be known as German Cinematic Expressionism, despite the protests of scholars who insist that Weimar cinema (1918-1933) is much more than the two dozen or so Expressionist films. But even Thomas Elsaesser, whose thorough study Weimar Cinema and After: Germany's Historical Imaginary (2000) wraps up decades of research into the subject, admits that, despite their diversity, "in retrospect, a unity imposes itself on these films, their subject and stories" $(2000,3)$. "It seems," he goes on to say, "the films usually indexed as Weimar Cinema, have one thing in common - they are invariably constructed as picture puzzles, which consistently, if not systematically refuse to be tied down to a single meaning" $(2000,3)$. And, one feels tempted to add, open themselves most readily - and consistently, if not systematically - to interpretation in light of concepts borrowed from clinical psychology. Which is not surprising since, as Elsaesser writes, the most "significant utterances" of that time came from "the same three nineteenth-century thinkers: Nietzsche's genealogy of morals, Marx's notion of ideology, and Freud's concept of the unconscious" (2000, 152).

Indeed, the "deep and fearful concern with the foundations of the self" and the ensuing anxieties, could - and have - been attributed by Marxist scholars to the consequences of the humiliating post-war Weimar arrangements, which intensified the extant class struggle. ${ }^{1}$ These deep-seated psychological concerns and social anxieties could also be seen as having triggered what Friedrich

1 See Kristin Thompson and David Bordwell for a balanced review of German Expressionism and its social and political background (2003, 101-117). On the other hand, Marxist-based approaches to Weimar culture focus predominantly on the enormous influence of the Soviet avant-garde cinema of Eisenstein, Vertov, and Pudovkin (Braskén, 2014). 
Nietzsche describes as the "beginnings of the slave revolt in morality" and "the ressentiment of those beings who, denied the proper response of action, compensate for it only with imaginary revenge” (2006, 20, see also Sipiora 2016). And, as Kracauer's study and its followers demonstrate, the reflection of these concerns and anxieties on the Weimar screen inevitably made psychoanalysis a preferred approach for analysing German Expressionist cinema. All the more that the psychoanalytical utterances of Sigmund Freud, based on the symbolism of dreams, were already entering the mainstream intellectual discourse, thus undoubtedly influencing the filmmakers.

\section{Symbolism and Expressionism}

German Expressionist cinema - along with the visual arts, music, theatre, and literature - obviously plays a significant role in the imaginary revenge of the Expressionist Weltanschauung against capitalist modernity and Enlightenment rationalism, considered to be the major causes behind the slaughter at the fronts of WWI, and of the exacerbated exploitation of the masses that followed. However, the metaphysical shift in German cinema, mentioned above, is prompted not so much by the creative ressentiment and the socially critical impetus of the Expressionist movement, but by the indignation - shared by German Romanticism and the decadent French Symbolism - with the profanation and destruction, brought on by the Industrial Revolution, of the "'noble', 'aristocratic', 'spiritually highminded'" values (Nietzsche 2006, 13). German cinematic Expressionism came to be associated with the mysticism and melancholy of late German Romanticism usually projected on Medieval or Classical past, and with the Symbolist trend in paintings which - with its ancient ruins, majestic twilight landscapes, vertically elongated Gothic shapes, and almost pathological fascination with death and afterlife - represented a passionate escapist reaction to realism and naturalism of the 19th-century literature, art, and philosophy.

Moreover, the triumph of Eros over Logos, ${ }^{2}$ associated initially with Symbolism, acquired an increasingly ideological meaning after WWI with inward-looking movements like Expressionism, and certainly with Surrealism, both positioning themselves firmly against the rational and optimistic extroversion of Futurism and Constructivism which served, albeit briefly, as inspiration to ideologically opposite

2 According to Rowland, "Eros stands for psychic capacity of relatedness and feeling, while Logos - for spiritual meaning and reason." While she accepts these concepts, she critiques Jung's "alignment" of Eros with the feminine, and Logos with the masculine, as "contemporary Jungian analytic practice treats Eros and Logos as equally available to both genders” (2008, 185-6). 
but equally murderous regimes - Fascism and Communism - whose official figurative artistry was to eradicate all symbolism and abstraction in the 1930s.

\section{The Semiotic and the Symbolic}

It is worth mentioning that post-WWI philosophical thought also privileged the fluidity of symbols over the concreteness of words because of their inability, as Ludwig Wittgenstein writes, ${ }^{3}$ to express imponderable values like "religion, the meaning of life, logic and philosophy" (Monk 2005, 17-21). Yet it is the major developments in analytical psychology - more specifically the publication in 1912 of the first version of Symbols of Transformation (revised in 1952 as Psychology of the Unconscious) by the Swiss clinical psychologist Carl Gustav Jung - which brought to the fore the importance of symbols for the human psyche. In addition to making public his break with Freud by openly declaring a radically different stand on the contentious issues of the collective unconscious ${ }^{4}$ and the nature of the libido, ${ }^{5}$ it established a different way of handling symbols. Rather than explaining them away, as Freud proposed in his Interpretation of Dreams (1899), Jung suggested amplifying them. Thus amplification was gradually accepted as "a general comparative strategy for exploring symbolic meaning" of 'primordial images' - later called archetypes ${ }^{6}$ - from the collective unconscious (Smythe 2012, 155).

Fittingly, Jungian scholar William Smythe relates amplification to " discovery procedure' rather than to method of verification," since its goal is "to exemplify, elaborate and embellish meaning without ever exhausting or explaining it" (2012, 154). Such a "distinction between the conceptual" - or the semiotic - and "the

3 In Tractatus Logico-Philosophicus Ludwig Wittgenstein affirms that "a picture is a model of reality" (Proposition 2.12) since "what a picture represents is its sense" (Proposition 2.221), yet is quick to warn us that "it cannot be discovered from the picture alone whether it [that is, the sense of reality] is true or false" (Proposition 2.224) (2015, 16-18). Therefore his last Proposition, no. 7 , proclaiming that "whereof one cannot speak, thereof one must be silent," could be read, among other things, as a critique of the complexity of philosophical conceptualization but also as a nod to the domain of the non-conceptual, that is, the symbolic $(2015,109)$.

4 In later writings Jung uses the term objective psyche.

5 While Freud defines the libido as predominantly sexual in nature, Jung insists that the libido is the psychic energy in general, and therefore of quantitative, not qualitative nature.

6 According to Smythe, "Jung used the term archetype to refer to basic patterns or forms of meaning that are widely distributed across cultures and reflect perennial, existential concerns of human life everywhere [...]. In his final, definitive reformulation of the theory of archetypes, Jung distinguished archetypal expressions, in the form of personal images and cultural symbols, from the archetype as such, which he conceived as 'irrepresentable' and generally non-amenable to conceptual articulation or explicit representation” $(2012,152-53)$. 
non-conceptual" - or the symbolic - could be compared to "the contrast between the denotative function of conceptual language and the expressive function of symbols" (Smythe 2012, 154). In addition to "the individual productions of patients in psychotherapy," amplification is thus successfully applied "across a wide range of diverse contexts," including "cultural products of religious and mythological traditions" (Smythe 2012, 154), and certainly - in literary and art criticism (see Susan Rowland 2010, 2013, and 2018). As Post-Jungian film scholar Don Fredericksen remarks, amplification is the only possible way of grasping "the extraordinary fascination," experienced when symbols from the objective psyche (or the collective unconscious) captured on screen, "transcend the personal association" of the conscious mind $(2001,29)$.

In his seminal article "Jung/sign/symbol/film" Fredericksen - basing his argument on Jung's understanding of sign and symbol - emphasizes amplification as an indispensable tool for the symbolic approach to film. In his view, the extant semiotic approaches, which he defines as brought on by the "rationalistic hubris" - Christian Metz's theory of the Imaginary Signifier, Freud- and Lacan-inspired theory, and Marxism - are aimed at explaining rationally every symbol, and turning it into sign once and for all $(2001,28)$. He then contrasts Freudian semiotics and Jungian symbolism on the basis of their approach to "the incest imagery" in the Oedipus complex. While Freud found this imagery "annoyingly persistent" even after the "concretistic, allegedly semiotic meaning was made time and again conscious to the patient" (Fredericksen 2001, 19), Jung saw "what appeared to Freud as mere regression into the infantile [...] as a necessary step into the 'maternal depths' for spiritual unfoldment and psychic wholeness" (Fredericksen 2001, 19). In other words, Freud aimed at explaining away psychic material in rational terms and Jung encouraged amplification of its symbolism. Fredericksen concludes that "while the majority of films are predominantly semiotic in character [...] and [represent] manifestations of social codes" (Fredericksen 2001, 27), a number of avant-garde, experimental works are construed like "symbolic products of the psyche," which would "lack in meaning were not a symbolic one conceded to them" (Jung qtd. in Fredericksen 2001, 27). Fredericksen's approach to the semiotic and the symbolic follows closely Jung's understanding of "psychological" or "introvert" and "visionary" or "extrovert" art.7 Thus in Jung's view, Part I of Faust is an example of psychological or introverted art, which yields

7 What is meant by introvert and extrovert here is that psychological art is self-sufficient, enclosed within itself, while the visionary is open, and entirely dependent on the recipient for interpretation. 
to Fredericksen's semiotic approach, since it remains within the boundaries of the human experiences and human consciousness. Unless, of course "we expect [to be explained] why Faust fell in love with Gretchen, or why she was driven to murder her child" (Jung 1989b, vol. 15, 88-89). In Part II, however, "the material for artistic expression is no longer familiar," it is "something strange that derives its expression from the hinterland of man's mind, as if it had emerged from the abyss of pre-human ages, or from a superhuman world of contrasting light and darkness, [...] a primordial experience which surpasses man's understanding and to which in his weakness he may easily succumb" (Jung 1989b, vol. 15, 90).

\section{The Psychological Cinema of Robert Wiene}

In her succinct way, post-Jungian scholar Susan Rowland clarifies further the above division by suggesting that "psychological art expresses mainly the collective consciousness of a society," and that "the artist has already done most of the psychic work for the audience" $(2008,187-8)$. With this in mind, it is easy to see why Robert Wiene stands out among the few Expressionist directors of psychological cinema, who seek to "express what the collective is consciously debating or concerned about," and ensure that a rational explanation of the numerous mysterious occurrences in their films is obtained (Rowland 2008, 88). Thus the viewer - as Tzvetan Todorov has it in his discussion of the fantastic - after some "hesitation between the natural and the unnatural explanation of the events described," is steered towards the conclusion that "the laws of reality remain intact," and "the work belongs to the uncanny" (Todorov 1975, 41). In The Cabinet of Dr. Caligari (Das Cabinet des Dr. Caligari, 1920) for example, the protagonist, Frank tells a strange story about the head doctor of a local mental hospital, who in some mysterious ways has adopted the personality of the medieval necromancer Caligari, and is committing a series of murders by the hand of Cesare, a malleable somnambulist in his care. Until the very end of the film Wiene masterfully coaxes viewers' hesitation as to whether Frank's story belongs to the realm of the unexplained and the "marvelous," where "new laws of nature must be entertained to account for the phenomena," or is a case of psychotic transference where patients project - or unconsciously transmit phantasmagoric desires and aggressive impulses - on their doctor (Todorov 1975, 41). The hesitation reaches its climax in the penultimate scene, where Frank confronts the head doctor publicly: "you think I am insane? It is the director who is insane! He is Caligari, Caligari, Caligari." Weine - in tune with Freud's musings about transference being 
sometimes "the best tool" in psychiatric treatment, but also "its greatest threat" (Demir) - resolves the hesitation in favour of the "natural laws of reality." And lets the doctor utter the final words: "at last I understand his delusion. He thinks I am that mystic Caligari, now I know exactly how to cure him.” [Fig. 1.]

For The Hands of Orlac (Orlacs Hande, 1924), Wiene adapts the eponymous novel by Maurice Renard, the forerunner of the dystopian bio-punk subgenre. And makes the story about the transplantation of a murderer's hands onto the talented pianist Orlac, who has just lost his in a horrific railway accident, as selfexplanatory and as rationally explicit as possible. He excelled in this endeavour to such an extent that, as an excellent blog on silent cinema affirms, "the Interior Ministry of Saxony tried, without success, to have the film prohibited" for giving "too detailed information on the working methods of the police [which they believed] could give criminals ideas to commit a crime without being caught" (A Cinema History). Yet again, the nocturnal scene of the train crash, and especially the scenes where Orlac is seized by terror, imagining the acts his new hands might be capable of, are designed with stunning Expressionist elegance, both uncannily macabre and out-worldly marvellous.

Wiene's Raskolnikov (Raskolnikow, 1923), along with Friedrich Wilhelm Murnau's Tartutfe (Tartüff, 1925) and Fritz Lang's Dr. Mabuse, the Gambler (Dr. Mabuse, der Spieler, 1922), also belong to this category as their psychological conspicuousness stems from their famous critical-realist literary prototypes. And while the unusual camera angles, chiaroscuro lighting, and the generally gloomy nocturnal atmosphere - or their Stimmung as Lotte Eisner would have it - are unquestionably Expressionist, they are hardly original. Or, as Dr. Mabuse's somewhat self-derogatory comment sums it up: "Expressionism is mere pastime ... but why not? Everything today is pastime!” (A Cinema History).

\section{Shadows, The Weary Death, and Waxworks as Visionary Art}

According to Rowland, "visionary art is primarily expressive of the collective unconscious. As such it compensates the culture for its biases, brings to the consciousness what is ignored or repressed, and may predict something of the future direction of a culture" (italics in the original, 2008, 189-90). In any case, neither ego, nor consciousness cannot be "excluded from a work of art, so nothing is hundred percent of the unconscious," therefore "visionary and psychological [art] are linked categories pushed apart to polar extremes, not wholly different realms" 
(Rowland 2008, 190). Unlike the psychological works, discussed above, the three visionary works under scrutiny here have remained on the margins of most seminal writings on German Expressionism, since semiotic approaches fail to capture their symbolic energy - always already open to any number of meanings conceded to them - generated by the manifestation of the archetypes at their core. Thus Arthur Robison's Warning Shadows (Schatten, 1923), Fritz Lang's The Weary Death aka Destiny (Der müde Tod, 1921), and Paul Leni’s Waxworks (Wachsfigurenkabinett, 1924) are amplified in terms of the shadow, the anima, and the animus, which also happen to be the archetypes "most clearly characterized from empirical point of view," because of their "most frequent and most disturbing influence on the ego" (Jung 1968, vol. 9ii, 8). To quote Jung again, their amplification elucidates the fascination with "something strange that derives [...] from the hinterland of the mind"- that is, from the collective unconscious, and therefore yields "new laws of nature," coming from the "realm of the fantastic marvelous" as Torodov suggests.

Warning Shadows (subtitled A Nocturnal Hallucination) is a lesser known, but very original film which, as its title implies, creates a riddle of shadow symbolism, which works on semantic, religious, mythological, and archetypal level. And to reduce its meaning to any of those aspects would result in "impoverishment of the emotive experience, of its imaginal and affective mass" (Mario Trevi qtd. in Connolly 2008, 129). The film is above all an exquisite aesthetic rendition of the art of shadows, deployed by Robison as visions, emergent "from a superhuman world of contrasting light and darkness," but also as extravagant commentaries of the unfolding events in a film without a single intertitle.

Shadows features a group of small town aristocrats, gathered for a lavish dinner party at the house of a rich and jealous husband who, unbeknownst to them, has set up an experiment to test his beautiful wife's fidelity. While prying on her, the host is increasingly tormented by the deceptive shadows on curtains and walls, which transform the guests' courting gestures into actual intimacies.

At this point, the shadows - along with the forceful chiaroscuro effect of the ubiquitous low-key lighting - are playful, even meta-cinematic comments on the shadows as a staple aesthetic trope of German Expressionism. [Fig. 2.] They represent "a pregnant metaphor that translates [...] the everyday experience" into "knowledge that we have a 'twilight zone', an obscure part of ourselves in which many presences reveal themselves" (Connolly 2008, 129).

As fate would have it, however, the host's sadomasochistic designs are frustrated by a travelling Illusionist who is eventually allowed to present a Chinese shadow-play to the party. The man swiftly grasps the situation, and aggravates 
deliberately the host's obsession by placing a lamp behind his dancing wife thus revealing her body under the dress. Prompted by the menacing silhouettes on walls and surfaces, the mood becomes foreboding, preparing the viewer for the most intense part of the film, where the symbolic - archetypal - meaning of the shadow is homologised to that of evil.

Once everyone is seated at the table, facing a screen, the Illusionist begins his hypnotising screening of a shadow-play about a Chinese Emperor, his unfaithful wife and her lover, whose allegorical implications are as essential to the personages as they are to the viewers. [Fig. 3.] Half way through the show, however, when the Emperor is about to behead the lover and punish the wife, the Illusionist makes the shadows of everyone at the table disappear, and a dissolve transition shows them sitting at the other side of the table.

Indeed, the shadow flaunts a typical archetypal duality - of life, as "the bond that ties us to the earth" - but also of "the black ghost that emanates from us, revealing the death within us" (G. Meyrink qtd. in Huckvale 2018, 52). In addition to being "the most accessible" archetype, and "the easiest to experience" (1968, vol. 9ii, 8), Jung understands the shadow as potentially both positive and negative due to its capacity to challenge "the whole ego-personality" (qtd. in Sharp 1991). The enormous psychological and moral difficulty in coming to conscious terms with one's shadow explains its tendency to project itself on others, which paradoxically remains the only empirical way of exploring it. Thus the shadowselves of Robison's personages - their murderous desires, vulgar urges, and morally inferior drives - are acted out on the screen before their minds' eye. As a result, the wife's intensifying flirtatiousness, the growing boldness of the lascivious guests, and especially that of the most handsome one, called the Lover, play in the hands of the crafty husband, who ultimately is seen as forcing the guests to stab his fettered wife to death and then challenging them to a deadly sword-fight.

At this crucial moment of the illusionary tale, the shadow-player, after having restored their shadows, wakes up the party. In this manner, Robison captures the shadow transition as an instrument of death and evil, to a nurturing force, which gives "corporeality and depth to the human body" (Connolly 2008, 129). Hosts and guests thus find themselves at the table in the position they were before the Illusionist mesmerized them, watching the end of the shadow-play, where the Emperor forgives his wife, they kiss, and even the miraculously resurrected lover leaves unharmed. Forewarned by the vision of the tragedy that was awaiting them, the guests hastily bid their good-byes, husband and wife embrace, and the mysterious shadow-player leaves the courtyard of the castle, riding a pig. 
In his comments on Warning Shadows, Kracauer writes that Robison's film, along with an episode from the second Wegener's Golem (1920) - where Rabbi Loew's mythical Golem, "by means of magic," makes the "panic-stricken Emperor" rescind his orders for evicting the Jews and stems the ensuing destruction - were the only cinematic instances at that time where reason and forgiveness prevailed (1974, 123-4). Yet the engagement of German Expressionist cinema with irrational and dark sides of the human psyche was a worthy, albeit short-lived attempt to capture on screen the propensity of neglected shadow contents to break out in neurosis and violence on individual and mass scale, and even coalesce as autonomous entities. It is enough to evoke the deadly outbreak of dark drives and desires in Georg Wilhelm Pabst's The Treasure (Der Schatz, 1923), in Fritz Wendhausen's The Stone Rider (Der steinerne Reiter, 1923) and the advent of Nosferatu in the small German town of Wisborg. The eponymous vampire from Murnau's 1922 classic, hailing from the Balkans - widely perceived obscure and therefore dangerous - is an exquisitely autonomous manifestation of shadow contents of xenophobia and bigotry, repressed in the personal and collective unconscious.

Writing with the devastating outcomes of WWII in mind, Jung sums up the dangers of identifying entirely with one's rational mind (or ego personality). Such one-sidedness, he warns, invariably leads to a Dr. Jekyll-Mr. Hyde kind of split on individual level, and to a Cold War standoff - on a political-economic and ideological one (1955, 1-94). He advises that instead of trying to "convince ourselves and the world that it is only they (i.e. our opponents) who are wrong [...], it would be much more to the point to make a serious attempt to recognise our own shadow and its nefarious doings" $(1955,73)$. Then again, the personal shadow has long been considered a "symbol of the soul," and it is through its recognition that the ego-personality becomes aware of the animus ${ }^{8}$ and the anima,${ }^{9}$ the unconscious male aspect in a woman, and the female aspect of a man (Connolly 2008, 129). Yet, as Rowland warns, neither the anima, nor the animus "lock Jungian theory into perpetual gender opposition," since the "archetypes

8 The inner masculine side of a woman, like the anima in a man, the animus is both a personal complex, an archetypal image, and a compensating masculine element in woman, providing her unconscious, so to speak, with a masculine imprint, therefore "I have called the projectionmaking factor in women the animus, which means mind or spirit. The animus corresponds to the paternal Logos just as the anima corresponds to the maternal Eros" (Jung qtd. in Sharp 1991).

9 Called by Jung the "archetype of life itself" and the "inner feminine side of a man," the anima is both a personal complex and an archetypal image of woman in the male psyche. "It is an unconscious factor [...], responsible for the mechanism of projection. Initially identified with the personal mother, the anima is later experienced not only in other women but as a pervasive and creative influence in a man's life” (qtd. in Sharp, 1991). 
of the unconscious are androgynous, and therefore masculinity as well as femininity," are among the "series of 'otherness' for the psyche" of a man or a woman $(2008,184)$.

According to Jung, individuation, or psychological maturity - that is, the actualizing of the archetype of the self by freeing it from "the false wrappings of the ego-persona and of the suggestive power of primordial images" and their projections - is impossible without the awareness of the internal other, or of the animus/anima forces of the unconscious (Jung qtd. in Sharp 1991). For, as Jung suggests, if the "encounter with the shadow is the 'apprentice-piece"” in a person's development, then "the reconciliation with their anima - and, for that matter, with their animus, would be their 'master-piece"” (Jung qtd. in Sharp 1991).

It is therefore intriguing to look at Lang's The Weary Death, known also as Destiny, and Leni's Waxworks not only as doppelgangers in structural sense, but also in psychological, as metaphorical expressions of the protagonists' quests for individuation with the help of their animus and anima, respectively. Both works represent aesthetically accomplished musings on death and love, set in different historical times in far-flung corners of the Earth, and played out in various genre modes, ranging from tragic and melancholy, to suspenseful, ironic, and even comedic.

Considered the first major work of Lang's oeuvre, Destiny features a griefstricken Young Woman who, after losing her beloved, pleads to Death personified by a sombrely handsome man - to let her have him back, and is given three chances to succeed if an avatar of hers saves the life of her beloved in one of the Stories of Light. Similarly, the protagonist in Waxworks, a poor Poet - asked by the proprietor of a fairground wax-museum and his daughter Eva to write tales about famous historical figures - imagines his newly-found love for Eva put to the test in three segments, animated by the famous personages and their times.

The bizarre locations in both films were obviously chosen with their mystical potential in mind, hence the Middle Eastern cityscapes [Figs. 4-5], the snowy vistas of Medieval Russia or the bridges of Venice and the jungles of China, with their oneiric atmosphere, point to the archetypal nature of the protagonists' experiences. Moreover, despite of their ostensible geographical and historical scope, these two films - "in diametrical opposition to nineteenth-century historicism" - bring to bear "a visual poetics of parallelism and homology, emphasizing trans-historical affinities and commonalities rather than distinct inner principles” (Baer 2015, 146). Indeed, the deployment of oddly shaped edifices and visual patterns underscores the metaphorical-mythological nature 
of the narratives, making these films representative pieces of visionary cinematic Expressionism, whose ultimate goal is just that - to express, "to show, or metaphorically exemplify" archetypes, "rather than to explicitly describe and conceptualise [their] meaning" (Smythe 2012, 154).

The quest of the Young Woman through time and space could therefore be amplified as a movement towards restoring "the lost mediation between her conscious and unconscious" mind, severed with the untimely passing of her male other, the animus. Each film segment hence corresponds roughly to one of "the four stages of animus development and the philosophical or religious ideas" associated with it, and to "the attitude resulting" thereof (Jung qtd. in Sharp 1991). Like Perceval, in her naïveté the Young Woman has stumbled upon the Grail of love unconsciously, lost it, and then - after an emotionally and spiritually excruciating quest - finds it again. But not before her unconscious self-sacrificial impulses transcend the ego-desires, and become a consciously selfless expression of her individuation.

In the first segment, the Young Woman's avatar is Princess Zobeide, the sister of the Calif in an imaginary Middle-Eastern City of the Faithful. She is passionately in love with the adventurous, trigger happy Frank, ${ }^{10}$ a Christian, who is the first incarnation of the lost beloved. The sexually and religiously transgressive nature of their attraction is underscored by the time and place of their secret meeting - during the holy month of Ramadan, at the central Mosque. The settings and the mise-en-scène, especially the ritual dance of the ascetic Dervishes - staged realistically, but lit and shot in expressionist manner - enhance the exoticerotic charge of the story. As is to be expected, their forbidden love is crushed by Zobeide's mighty brother, and Frank is buried alive by the Calif's gardener El Mot, who is actually Death.

In the second segment - the least visually inventive and, because of its melodramatic narrative and stock characters, the most clichéd - the projection of the Young Woman's animus is no longer "embodiment of physical power" and sexual prowess, but inspires "desires for independence" in the noble Monna Fiametta, her new avatar (Jung qtd. in Sharp 1991). Unfortunately, the object of this desire is the characterless Giovan Francesco - the second reincarnation of the lost beloved - whose greatest virtue is his youth and absolute dedication to Monna. And although the animus here motivates her "initiative and capacity for planned action," the Young Woman fails again to take into account the power of the other man who wants to possess her (Jung qtd. in Sharp 1991). Taking

10 Frank could be understood as a personal, but was also a generic name for a European Christian. 
advantage of the wild Venice Carnival, her cunning older suitor arranges that Giovan Francesco is killed instead of him, and with the poisoned knife, yielded by Monna Fiametta's loyal servant, who is actually Death.

The third, Chinese segment, is the best crafted one, boldly juxtaposing realist shots with Expressionist interiors and lighting. [Fig. 6.] Fittingly, its overall ironic mode and actors' self-reflexivity echoes the growing independence of the Young Woman, now on her way of mastering both her conscious and unconscious mind. In this third stage, the animus is "often personified as a professor or clergyman," the archetypal wise old man, a role fulfilled here by the old magician A Hi, whose ingenious disciple her avatar Tiao Tsien is (Jung qtd. in Sharp 1991). As A Hi's trusted assistant, Tiao Tsien is poised to surpass him, which she eventually does by turning the old man into an ugly cactus. The role of her beloved, however, is reduced to that of an erotic playmate, an object of desire whose only dramatic function is to advance the plot. And when the greedy Emperor demands that A Hi gives him Tiao Tsien as a birthday gift - along with the flying carpet, the winged horse, and the miniature army - she flees with her beloved Liang. What follows is a sequence of magic tricks - performed by Tiao Tsien to frustrate the pursuers - whose cinematographic inventiveness has beautifully survived the passage of time. Yet despite of camouflaging Liang as a jungle tiger, he is pierced through the heart by Death - who appears here as the Emperor's best archer - while Tiao Tsien, disguised as a Buddhist statue, sheds stone tears.

The desperate Young Woman then finds herself back with Death who, in this fourth and final stage, epitomizes her animus as "the incarnation of spiritual meaning," a "helpful guide," the one who mediates between life and death, reality and unreality, consciousness and the unconscious, and plays an indispensable role in her individuation (Jung qtd. in Sharp 1991). Moved by her valiant selflessness, Death gives the Young Woman yet another chance to save her beloved if she were to convince someone to exchange their life for his. After a frantic search, the woman gets such a chance when she is about to leave a newborn baby perish in a fire, but decides against it. By accepting to take the saved baby to his mother, Death endorses this act of selfless appreciation for the "values of the collective," considered supreme manifestation of an individuated psyche and, as a reward, lets the Young Woman join her beloved in his realm (Sharp, 1991). [Fig. 7.]

Indeed, after Nietzsche proclaimed the death of God at the end of the 19th century, death has arguably remained the last metaphysical entity, whose numinous appeal is still felt in art, philosophy, and certainly in the media. Yet death as an 
archetype enjoyed a singular status in German Romanticism and Symbolism, and in its fin-de-siècle culture, influenced by morbid Gothic mysticism. And certainly in cinematic Expressionism, whose engagement with death in its various symbolic and narrative hypostases intuited an ominous constellation of a death-wish in the collective unconscious. ${ }^{11}$ This serendipitously prophetic insight throws light on the enduring fascination with Death in Destiny, resuscitated more than three decades later by the equally mesmerizing figure of the chess-playing Death in The Seventh Seal (Det sjunde inseglet, Ingmar Bergman, 1957).

In addition to anima and death, Lang's film engages with other archetypes, three of which are directly related to the discussion at hand - that of the quaternity, of the senex and the puer aeternus. The senex or old man, is metaphorically exemplified by Zobeide's Brother, Monna Fiametta's suitor, and the Emperor of China, while the puer aeternus, or the eternal boy, is manifested in the avatars of the Young Woman's beloved. Being each other's shadow, the "disciplined, controlled, responsible, rational, and ordered senex" is "associated with the god Apollo," while the puer is "related to Dionysus-unbounded instinct, disorder, intoxication, whimsy" (Sharp 1991). The senex is also counterpoised by the archetype of the wise old man, who in the film is embodied, albeit ironically, by A Hi, and of course, by Death.

The inevitable finitude of the Young Woman's decision is supported by the archetype of quaternity, which, according to Jung, "points to the universal idea of wholeness" and is manifested in the four-fold structure of the film (qtd. in Sharp 1991). Thus "the cross, formed by the points of the quaternity" could be interpreted as a symbol of moral imperative - that is, to bear her cross by obeying to patriarchy or the Law of the Father (as Lacan has it), symbolized by rigidified, controlling and blocking older males. Or spend her life saving, in a literal and figurative sense, her beloved puer - or follow Death, the only wise and compassionate male presence in the film (Jung qtd. in Sharp 1991). This Jungian approach to the fate of an individuated woman yields an unexpectedly prophetic layer of meaning to Destiny, further corroborated by the discussion of Paul Leni's Waxworks.

Unlike Destiny, the overall mood of Waxworks is lighter, at times even selfironic, and the structure of the film, reflecting the erratic individuation process

11 Catalysed after 1933 by the officially endorsed pessimistic eschaton (or myth about the end of the world) of Norse mythology, and the constellation of (the god of war) Wotan archetype in the collective unconscious, this collective death-wish brought about the conflagration of WWII (see Jung's Wotan essay at http://www.cgjungpage.org/learn/articles/analytical-psychology/47jungs-shadow-two-troubling-essays-by-jung. Last accessed 30. 03. 2019) 
of the protagonist - a quintessential puer aeternus, known by the generic name the Poet - consists of three segments instead of four, framed by an introductory and a conclusive episode. Needless to say, the handsome Poet leads poor and provisional, "more or less imaginary" life due to "fear of being caught in a situation from which it might not be possible to escape" (Sharp 1991). Ironically, he imagines himself caught in three such situations, two of which he overcomes thanks to the lovely Eva, who appears as personification of his anima.

The first segment is a playful rendition of motifs from the Middle-Eastern One Thousand and One Nights tales, featuring the fabulously rich sultan Harun-al Rashid, and the Poet as his neighbour, the poor baker Assad. Instead of beheading him for polluting his palace with smoke from the bakery chimney, the sultan falls for his beautiful wife Zarah, a personification of the Poet's anima, who evokes a universally coveted "collective and ideal sexual image," which - as Jung implies - is "modelled after Helen of Troy," and is every bit as shrewd as her historical prototype (Sharp 1991). Obsessed with the near-impossible task to strike it rich, Assad decides to steal the sultan's famous wish-fulfilling ring, which would secure the good life for his beloved Zarah. And, as only a fairy tale would have it, while Assad is sneaking into the palace, the sultan clandestinely finds his way to Zarah's place.

The ring Assad brings back - along with the arm of the sultan's wax doppelganger left in his bed for conspiracy purposes - turns out to be false, pointing to the Poet's bungled individuation. Which is to be expected from a puer, who never gets things right and subconsciously sabotages success. What is more, the falsity of the ring - otherwise a symbol of psychological wholeness - complicates even further his quest for maturity. Yet instead of a bloody confrontation with his powerful rival, his anima, that is Zarah - in a twist, worthy of Shahrazad succeeds in mediating the dangerous puer-senex standoff by wrapping both the jealous Assad and the lascivious sultan around her finger.

Visually, this segment is as seamlessly expressionist with regard to settings, lighting, and acting, as are From Morn to Midnight (Von Morgens bis Mitternacht, Karlheinz Martin, 1920), Caligari, and some episodes of The Hands of Orlac. The rounded shapes and irregular cavities of its exquisite, Antoni Gaudí-like décor force the sultan to drag his corpulent body in and out of Assad's strange abode, thus externalizing the challenges of the forbidden love. [Fig. 8.] Assad's tortuous movement through the maze of spiral passages, on the other hand, symbolizes the Poet's descent into the nurturing pits of the collective unconscious for it is there - according to the main theme in the visionary Part II of Faust - where "the 
Realm of the Mothers" is, and wherefrom "the creative process arises"12 (van den Berk 2012, 103).

The mood of the second segment, albeit sombre, is tinged with irony, stemming from the exotified world of Ivan the Terrible, the infamous late medieval Russian Tzar. The predominantly elongated and pointed architectural shapes - tailored after the tall-slim figure of the Tzar - counterbalance the rounded ones from the previous segment, apparently enthused by Harun al-Rashid's curvy forms. The skylines, though - defined here by the onion shapes of Russian orthodox churches - rhyme with the Middle-Eastern arches and minarets from the first segment.

The autocratic Tzar, a rigidified senex totally devoid of Eros, is "secretly [...] influenced by primitive impulses," like taking sadistic-voyeuristic pleasure in watching prisoners tortured in the Kremlin dungeons, and in colluding with his poison-maker to annihilate his enemies, yet living in mortal fear of assassins and poisoning (von Franz 1993, 112). Such a "negatively perceived paternal power figure" is bound to have a psychologically paralysing effect on the Poet's puer, embodied by the handsome Prince, who is about to marry a beautiful noble girl (von Franz 1993, 110). The bride - Eva's second avatar - personifies his pious anima which, according to biblical and other mythological traditions, is "manifested in religious feelings and a capacity for lasting relationships," symbolized by the Virgin Mary (Sharp 1991). When, mistaken for the Tzar, the bride's father gets assassinated, the Prince is stupefied by the latter's brutal "efforts to maintain his status of a privileged [...] voyeur" by forcing the grief-stricken wedding guests to make merry in order to entertain him (Telotte 2005, 23). Angered for having instead become a "subject of [...] their horrified looks," the Tzar - while preparing to defile the bride - sends the Prince to the dungeons to be tortured (Telotte 2005, 23).

Now, "dreams of imprisonment," along with "chains, bars, cages, entrapment, bondage" are "common symptoms of puer psychology," since "life itself is experienced as a prison," in comparison to the childhood the puer is so reluctant to part with (Sharp 1991). The Prince is saved at the last moment by the Tzar's sudden fixation with turning over incessantly an oversized hourglass, which has been used for counting down the seconds left before his victims die. A menacing symbol of mortality, the hourglass - along with its miniature version at the beginning of Destiny and the prominent town clock striking off the minutes, allotted to the Young Woman - signals the eerie timelessness of this "superhuman world of contrasting light and darkness, which surpasses man's understanding and to which in his weakness he may easily succumb" (Jung 1989b, vol. 15, 90).

12 So, by the way, believed Lacan, when defining his Imaginary Order as the domain of the Mother. 
The segment closes with the devastated bride - the Poet's anima, the archetype of life itself - cradling in a Pieta-like way the listless Prince in her arms, while watching the Tzar go completely mad.

Obviously alarmed by the stories spawned in the "hinterlands of his mind," the Poet approaches with a greater care Jack the Ripper, the third historical personage he is asked to write a story about. And, in an attempt to transcend his horrific misogynistic legacy, amalgamates him with the semi-mythological Spring-heeled Jack, known for attacking both males and females in 19th-century London and its vicinity. Yet, the Poet ends up with only a very short piece - about seven minutes screen time - which captures the finale of the third story. After having avoided, thanks to luck and his resourceful anima, the deadly face off with two murderous senēs - the Poet is fixated on the inevitability of a nightmarish flight from a third, and a much more dangerous one. And although the image of Eva flickers behind the barrage of superimpositions of Jack's wax figure, who blocks all exits, intensifying the Poet's sense of entrapment, it is not clear whether she is part of the story, or just a hallucinatory vision. And just when the Ripper is about to get him - and maybe also her! - the Poet wakes up with Eva by his side.

Despite the fast-paced editing, and the exquisite cinematographic tricks - or special effects - praised so much by Eisner $(2008,122)$, this segment is hardly "an acceleration near the end, typical of stories that employ suspense," as its brevity would have dragged the whole film down were it not contextualized so well symbolically (Coates 1991, 61). The ensuing conclusive episode therefore shows the Poet back where he was at the opening - at the writing desk in the claustrophobic confines of the wax-museum - before his imaginary quest for individuation began. In light of this, the short third segment could be seen as a flight from the forth - final, and most challenging - stage of individuation, where the "anima, symbolized as Sophia (or Wisdom), functions as a guide to the inner life," and a mediator between the conscious and the unconscious mind (Sharp 1991). The frightened Poet has instead chosen to return - or regress - to the stage where his anima, symbolized by the biblical Eve, or his love interest Eva, has become once again "indistinguishable from his personal mother" (Sharp 1991). Yet in this womb-like place, called significantly the Panoptikum (that is, Panopticon), the Poet is under the perennial watchful gaze of the three patriarchal tyrants, and therefore could hardly be driven to realizing the repressed "desire of a patriarchal eros [...] to reassert itself against the growth in feminine power" (Coates 1991, 62). On the contrary, the deadly designs of these senēs, if anything, are bound to catalyse the Poet's new quest for individuation through art which, 
for Jung, was "a highly effective form [...] because it is a confrontation with the other in the imagination" (Rowland 2008, 186). Such a quest would be the only way to release both himself and Eva from being stuck between the patriarchy of the senex and the womb-like domain of the mother, and transcend conformity or death as their only ways out.

\section{In Way of Conclusion: the Faust-Mephistopheles Dyad}

As seen so far, the psychological and the visionary art - although "not wholly different realms" of German Expressionist cinema - are, to quote Rowland again, still "pushed apart to polar extremes," but brought together again by the archetypal story of Faust and his unearthly enticer Mephistopheles. Inspired by legends about the medieval German alchemist and astrologer, the existential drama of Dr Faustus has become a central myth of European modernity thanks to Christopher Marlowe's play The Tragical History of the Life and Death of Doctor Faustus (1604), and certainly by Johann Wolfgang von Goethe's tragedy Faust (1832). Paradoxically, F. W. Murnau's Faust which, along with Metropolis (Fritz Lang, 1927) is among the last works Erich Pommer produced before his forced resignation as the head of UFA, and therefore executed on a lavish budget as a "cultural monument," in Kracauer's words "misrepresented, if not ignored" the significant motifs "inherent in its subject matter," thus turning the film adaptation into a "monumental display of artifice" $(1974,148)$.

When tracing the aesthetic and conceptual sources of German Expressionist cinema, Eisner, following Oswald Spengler, discusses the importance of what she calls the "Faustian soul' of the northern man," and juxtaposes its predilection for a world, "swathed in gloom," and "frightful solitude" - epitomized by the "Germanic Valhalla" - to the theatre of Max Reinhardt $(2008,51)$. He, as she reminds us, "was Jewish," and therefore "created his magical world with light," where "darkness served only as a foil to light" (Eisner 2008, 56). Canadian scholar Paul Coates homologizes Eisner's (and Spengler's) notion of the Faustian soul to that of Hans Schwerte's idea of the Faustian man, who "traduced" the Faustian myth to a symbol of "an ideology" of "the titanic German national destiny," dominating Wilhelmine Germany $(1991,29)$. Small wonder, then, that Faust - in a "symbiosis with Mephistopheles" - is considered as "the pervasive, frequently disguised hero of Weimar cinema" (Coates 1991, 30).

Jung, in turn, was interested mostly in the role of Mephistopheles as a Trickster figure, the shadow brother of Christ, so to speak. In Faust, he wrote, "I first 
found confirmation that there were people [...] who saw evil and its universal power, $[\ldots]$ and the mysterious role it played in delivering man from darkness and suffering" (1989a, 60). Religious historian Mircea Eliade comes to a similar conclusion when speaking about the "unexpected" mutual "sympathy' between God and the Spirit of Negation," that is Mephistopheles, since "for Goethe evil, and also error, are productive." Or as Goethe himself put it, "it is contradiction that makes us productive" $(1962,79)$. Thus, for both Eliade ${ }^{13}$ and Jung, ${ }^{14}$ this coincidence of opposites - or coincidentia oppositorum - is an imperative condition for understanding the workings of the human psyche and human life in general, and German Expressionist cinema offers an ample evidence of it.

In its various manifestations, the symbolic richness of the Faust-Mephistophelian dyad is at the core of the German Expressionist corpus. Thus The Earth Spirit (Erdgeist, Leopold Jessner, 1923), the first adaptation of Frank Wedekind's eponymous play, sees Lulu as a female version of Goethe's Earth Spirit. That is, a warning for trials yet to come and thus part of works - initiated by the succubus Genuine from Wiene's eponymous film from 1920, and closed by the false Maria in Metropolis - about vamp fatales, who like the Greek goddess Circe, tempt men into self-destruction by forcing their hidden depravities into the open.

Moreover, the Faust-Mephistopheles dyad has a decisive function in defining the genre mode, the character types, and above all, the psychological or visionary nature of Expressionist films. Thus in psychological works, the tandem is strictly divided into characters Elsaesser defines as "young, petit-bourgeois Fausts" - or Everymen Fausts - and those he calls "Mephisto figures" $(2000,66)$. It is enough to mention Nera (The Hands of Orlac), Scapinelli (The Student of Prague), or the title personages from Nosferatu, Tartuffe and Dr. Mabuse, to recognize the "Mephisto figures" as autonomous constellations of pure archetypal evil, meant to bring about the total demise of petit-bourgeois, Everyman Fausts. In visionary works, on the other hand, as has been demonstrated above by the Illusionist, the Death, and the three senēs, the Faust-Mephistopheles dyad works as coincidentia oppositorum, which throws in high relief the interrelatedness of evil and creativity, of temptation and inspiration, and of egotism and selflessness in the process of individuation. Indeed, as Jung has wittingly put it, it might never be known "what

13 Eliade finds evidence of concidentia oppositorum in religious myths about "the consanguinity of God and Satan, or of the Saint and the Devil-woman," which reflect "an obscure desire to pierce the mystery of the existence of evil or the imperfection of the divine Creation" (1962, 92-3).

14 For Jung coincidentia oppositorum or the transcendent function, fuelled by tensions of rationally irresolvable contradictions between conscious/unconscious, ego/shadow, anima/animus, has ultimately a positive transformative or transcendent impact on the totality of the Self. 
evil may not be necessary in order to produce good by enantiodromia ${ }^{15}$ and what good may very possibly lead to evil” (Jung qtd. in Sharp 1991).

\section{References}

Baer, Nicholas. 2015. Metaphysics of Finitude: Der müde Tod and the Crisis of Historicism. In A Companion to Fritz Lang, ed. Joe McElhaney, 141-161. Chichester: Wiley-Blackwell.

Braskén, Kasper. 2014. The International Workers' Relief, Communism, and Transnational Solidarity: Willi Münzenberg in Weimar Germany. London: Palgrave-McMillan.

Coates, Paul. 1991. The Gorgon's Gaze: German Cinema, Expressionism, and the Image of Horror. Cambridge: Cambridge University Press.

Connolly, Angela. 2008. Jung in the Twilight Zone: The Psychological Functions of Horror Film. In Psyche and the Arts, ed. Susan Rowland, 128-38. London, New York: Routledge.

Demir, Ayla Michelle. Transference and Countertransference in Qualitative Research. https://www.researchgate.net/publication/278847954_Transference and_Countertransference_in_Qualitative_Research. Last accessed 30. 03. 2019.

Dr. Mabuse, the Gambler. http://www.acinemahistory.com/2015/11/dr-mabuseder-spieler-1922-dr-mabuse.html?q=destiny. Last accessed 30. 03. 2019.

Elsaesser, Thomas. 2000. Weimar Cinema and after: Germany's Historical Imaginary. New York: Routledge.

Fredericksen, Don. 2001. Jung/Sign/Symbol/Film. In Jung \& Film: Post-Jungian Takes on the Moving Image, eds. Christopher Hauke and Ian Alister, 17-55. East Sussex, Philadelphia: Brunner-Routledge.

Goethe, Johann Wolfgang von. 1949. Maximen und Reflexionen [Maxims and Reflections]. Zürich.

Guffey, Rudolf. 2016. Here among the Dead: The Phantom Carriage and the Cinema of the Occulted Taboo. In Expressionism in the Cinema, eds. Olaf Brill and Gary D. Rhodes, 169-189. Edinburgh: Edinburgh University Press.

Huckvale, David. 2018. Movie Magick: The Occult in Film. Jefferson, North Carolina: McFarland and Co.

Jung, Carl Gustav. 1968. Aion: Researches into the Phenomenology of the Self. In Collected Works, vol. 9ii. Princeton, NJ: Princeton University Press.

15 Literally, "running counter to," referring to the emergence of the unconscious opposite in the course of time (Sharp, 1991). 
Jung, Carl Gustav. 1989a [1962]. Memories, Dreams, Reflections. Vintage Books: New York.

Jung, Carl Gustav. 1989b [1966]. Psychology and Literature. In The Spirit in Man, Art, Literature, Collected Works, vol. 15, 84-105, Princeton NJ: Princeton University Press

Kracauer, Siegfried. 1974. From Caligari to Hitler: A Psychological History of German Film. Princeton NJ: Princeton University Press.

Monk, Ray. 2005. How to Read Wittgenstein. New York: W. W. Norton.

Nietzsche, Friedrich. 2006. On the Genealogy of Morality. Cambridge: Cambridge University Press.

Rowland, Susan. 2008. Glossary. In Psyche and the Arts, ed. S. Rowland, 183190. London, New York: Routledge.

Rowland, Susan. 2010. C.G. Jung in the Humanities: Taking the Soul's Path. New Orleans: Spring Journal Books.

Rowland, Susan. 2013. Reading Jung for magic: "Active imagination” for/as "close reading." In How and Why We Still Read Jung, eds. Jane Kirsch and Murray Stein, 86-106. London, New York: Routledge.

Rowland, Susan. 2018. Jungian Literary Criticism: The Essential Guide. London, New York: Routledge.

Sharp, Daryl. 1991. Jung Lexicon: A Primer of Terms \& Concepts. Inner City Books. https://www.psychceu.com/Jung/sharplexicon.html. Last accessed 30. 03. 2019.

Sipiora, Philip. 2016. Nietzsche's Fingerprints on The Hands of Orlac. In Expressionism in the Cinema, eds. Olaf Brill and Gary D. Rhodes, 169-189. Edinburgh: Edinburgh University Press.

Smythe, William. 2012. Archetypal Hermeneutics as an Approach to the Psychology of Religion. Journal of Religious Studies and Theology vol.31, no. 2: 147-163.

Telotte, J. P. 2005. German Expressionism: A Cinematic/Cultural Problem. In Traditions in World Cinema, eds. Linda Badley, R. Barton Palmer, and Steven Jay Schneider, 15-28. Edinburgh: Edinburgh University Press.

The Hands of Orlac. http://www.acinemahistory.com/2016/06/orlacs-hande1924-hands-of-orlac.html?q=orlac. Last accessed 30. 03. 2019.

Thompson, Kristin and David Bordwell. 2003. Film History: An Introduction. New York: McGraw-Hill.

Todorov, Tzvetan, 1975. The Fantastic: A Structural Approach to a Literary Genre. New York: Cornell University Press. 
van den Berk, Tjeu. 2012. Jung on Art: The Autonomy of the Creative Drive. London, New York: Routledge. von Franz, Marie-Louise. 1993. Psychotherapy. Boston and London: Shambala. Wittgenstein, Ludwig. 2015. Tractatus Logico-Philosophicus. http://people. umass.edu/klement/tlp/. Last accessed 30. 03. 2019.

\section{List of Figures}

Figure 1. Robert Wiene: The Cabinet of Dr. Caligari (Das Cabinet des Dr. Caligari, 1920).

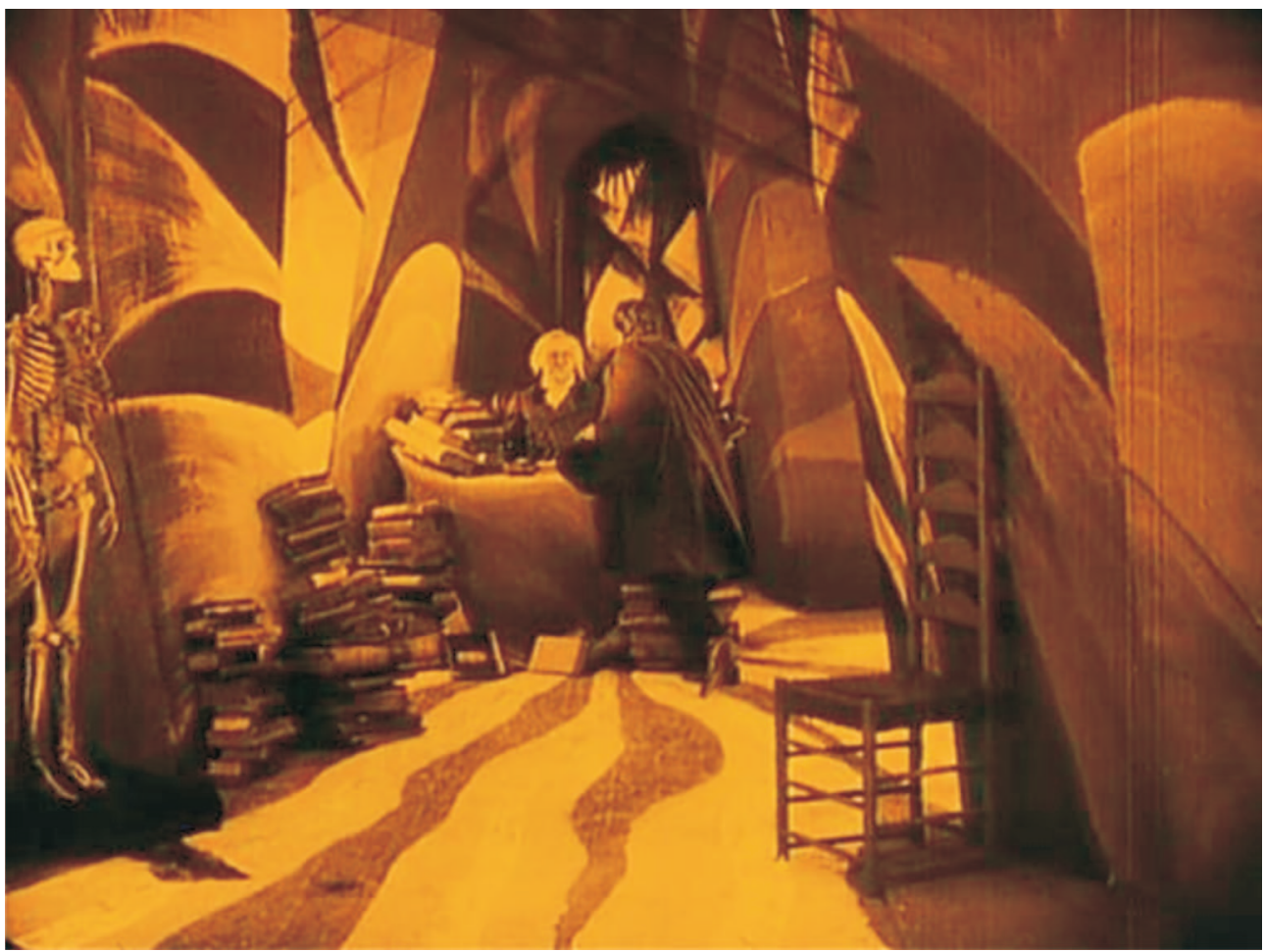


Figures 2-3. The shadows as a staple aesthetic trope of German Expressionism. Arthur Robison: Warning Shadows (Schatten, 1923).
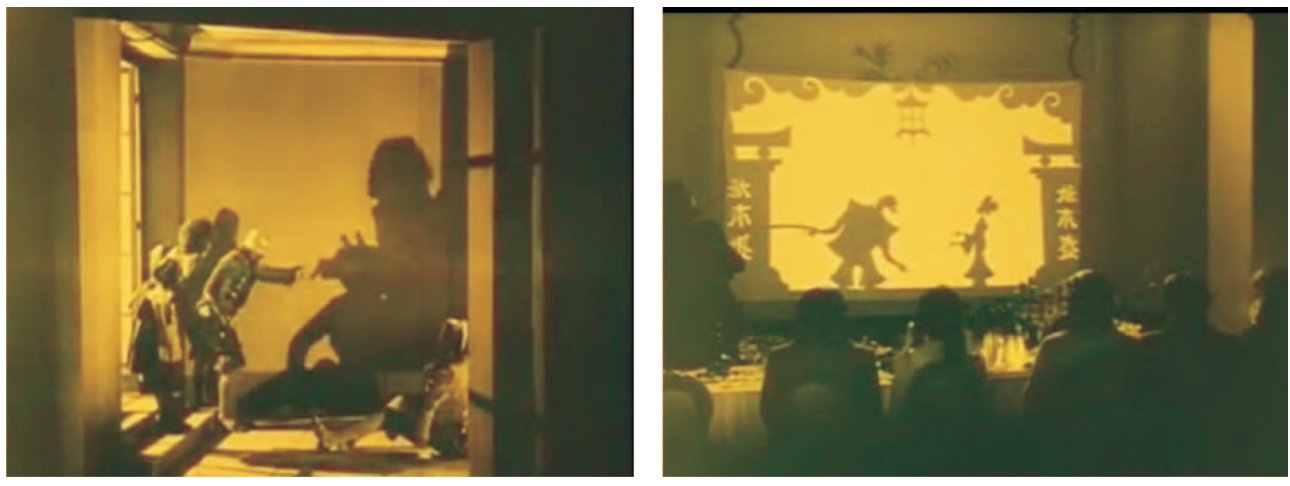

Figures 4-5. The mystical potential of locations in Fritz Lang's The Weary Death/ Destiny (Der müde Tod, 1921) and Paul Leni's Waxworks (Wachsfigurenkabinett, 1924).
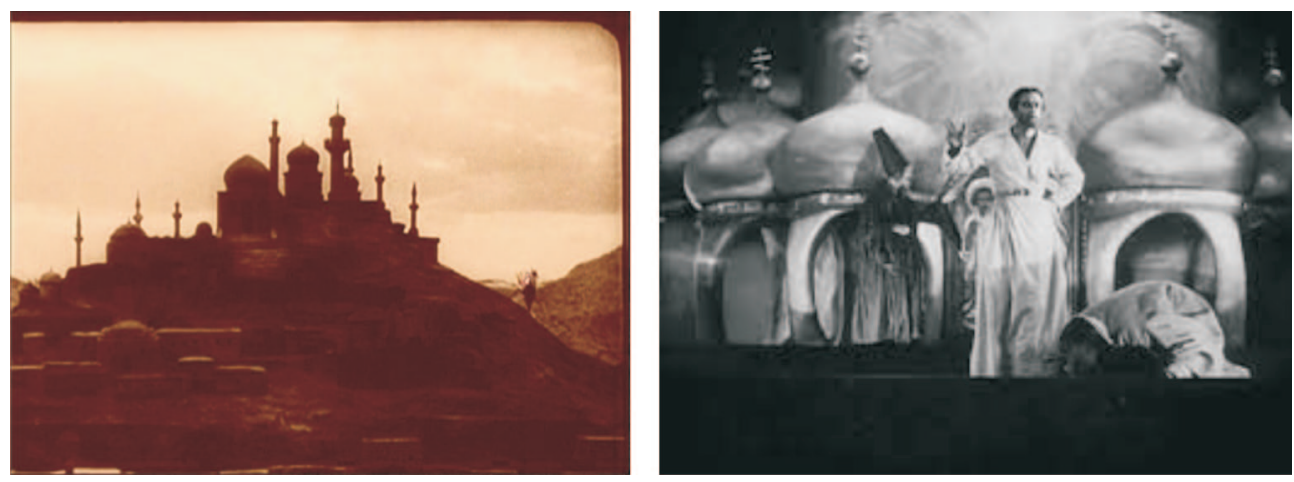

Figures 6-7. Fritz Lang: The Weary Death/Destiny (Der müde Tod, 1921).
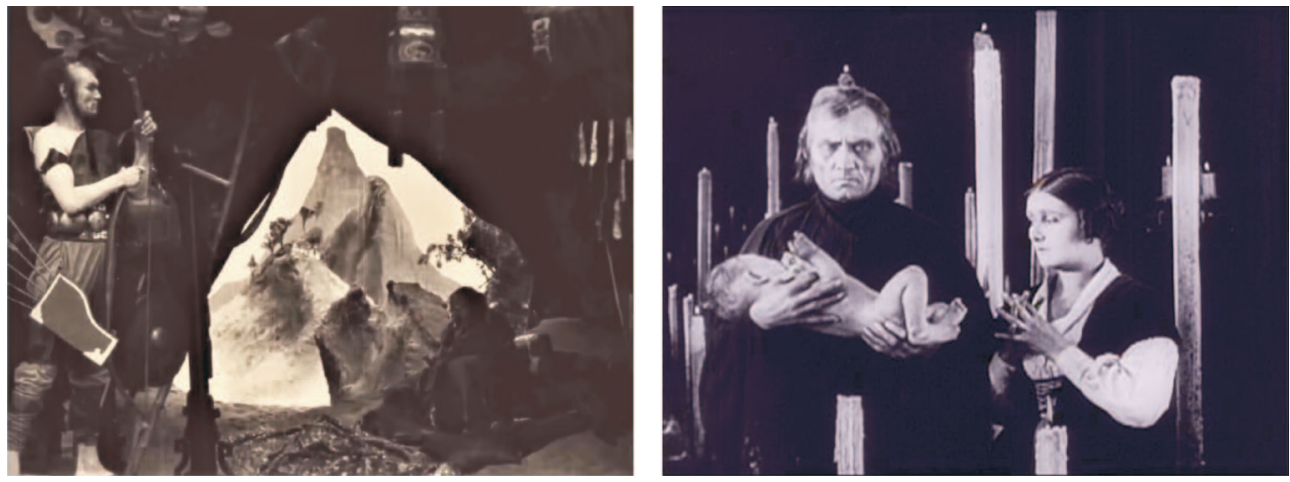
Figure 8. The Antoni Gaudí-like décor of Paul Leni's Waxworks (Wachsfigurenkabinett, 1924).

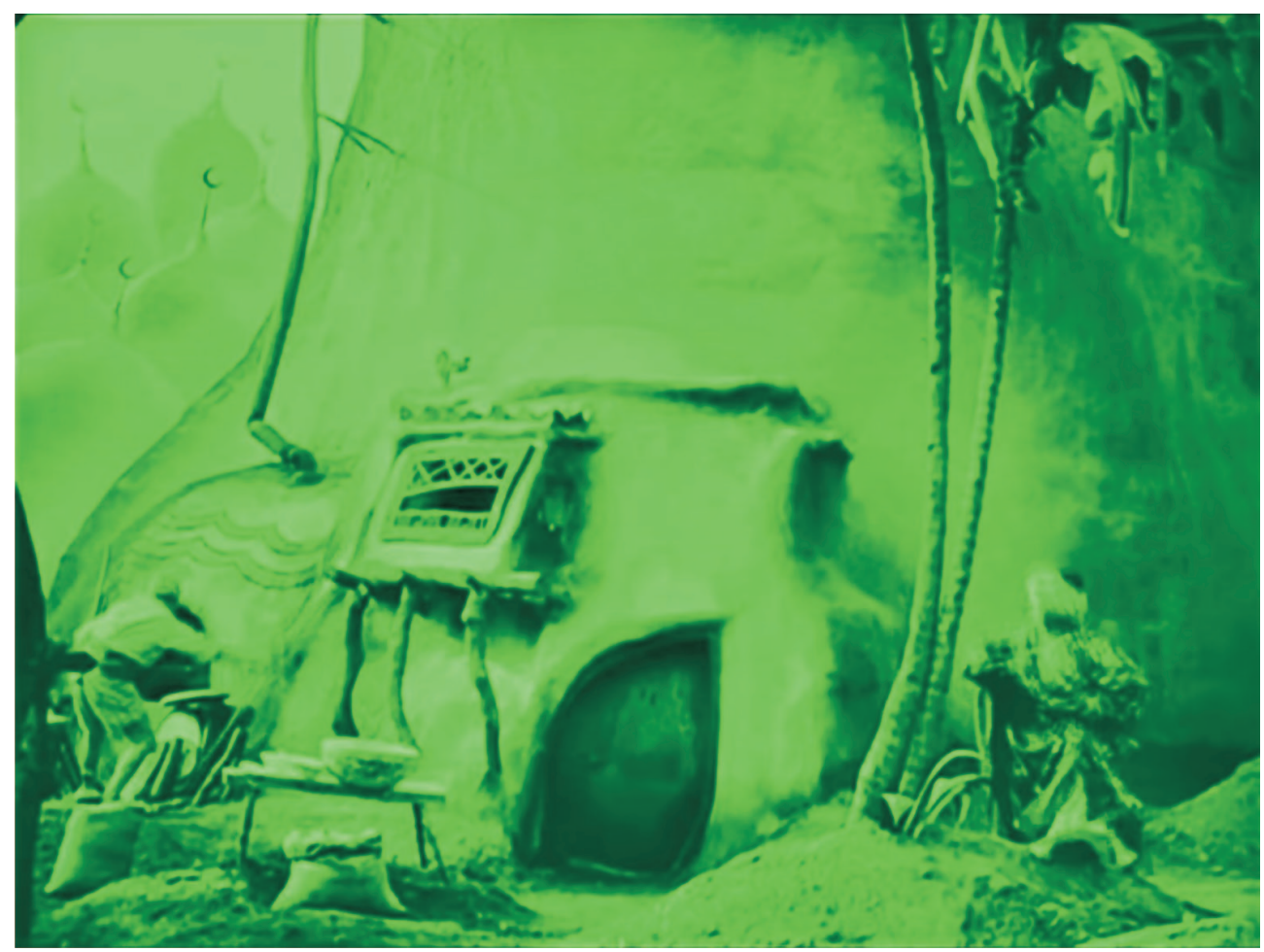

